\title{
CHROMOSOMAL INSTABILITY IN PERIPHERAL BLOOD LYMPHOCYTES OF PATIENTS WITH REPRODUCTIVE FAILURE ASSESSED BY MICRONUCLEUS ASSAY
}

\author{
Olivera MILOŠEVIĆ-DJORDJEVIĆ ${ }^{1,2}$, Ivana STOŠIĆ ${ }^{1}$, Darko GRUJIČIĆ ${ }^{1}$, Ivanka ZELEN ${ }^{2}$, and \\ Predrag SAZDANOVIĆ ${ }^{2}$
}

Faculty of Science, University of Kragujevac ${ }^{1}$, Faculty of Medicine, University of Kragujevac ${ }^{2}$, Kragujevac, Serbia

Received in February 2012

CrossChecked in August 2012

Accepted in August 2012

\begin{abstract}
We investigated chromosomal instability in peripheral blood lymphocytes (PBL) of patients with reproductive failure in respect to age, smoking habits, gender, miscarriages, and semen parameters. The study involved 36 individual cases of reproductive failure (18 men and 18 women) attended at the Clinical Centre of Kragujevac, Serbia, and 30 healthy subjects (15 men and 15 women). Micronuclei (MN) frequency was estimated in PBL using the cytokinesis-block micronucleus (CBMN) assay. The baseline MN frequencies were significantly higher $(\mathrm{p}=0.031 ; \mathrm{p}<0.001)$ in male $[(9.22 \pm 4.70) \mathrm{MN}$ per $1000 \mathrm{BN}$ cells $]$ and female patients $[(13.50 \pm 2.5) \mathrm{MN}$ per $1000 \mathrm{BN}$ cells] than in male and female healthy controls $[(6.27$ $\pm 2.66) \mathrm{MN}$ per $1000 \mathrm{BN}$ cells; $(6.80 \pm 2.98) \mathrm{MN}$ per $1000 \mathrm{BN}$ cells]. The mean baseline $\mathrm{MN}$ frequency did not significantly differ between miscarriage groups and between patients with and without normal values of semen parameters. The correlations between poor sperm concentration $\left(<20 \times 10^{6} \mathrm{~mL}^{-1}\right)$, rapid progressive motility $(<25 \%)$, normal morphology $(<30 \%)$, and $\mathrm{MN}$ frequencies were negative, but not statistically significant. We found that only gender significantly influenced the $\mathrm{MN}$ rates in analysed patients. There were no significant differences between age groups and between smokers and non-smokers in patients and control samples. We conclude that the increase in baseline MN frequency in PBL of patients with reproductive failure corresponds to the increase in chromosomal damage, which occurs as a result of complex events that cause reproductive disorders.
\end{abstract}

KEY WORDS: age, gender, infertility, micronuclei, semen quality, smoking

Infertility is defined as the inability to conceive after twelve months of regular unprotected sexual intercourse. It may be related to a variety of genetic $(1,2)$, as well as nongenetic factors (3-5).

Previous studies confirmed higher frequency of chromosomal abnormalities in the sperm of men with abnormal semen parameters $(6,7)$. Chromosomal abnormalities were also found in peripheral blood lymphocytes of infertile men (8,
9). Two comet assay studies $(10,11)$ reported a significantly higher level of DNA strand breaks in the sperm of infertile men compared to the controls. Duzcan et al. (12) suggested a greater incidence of sex aneuploidy in somatic cells of oligozoospermic men.

Female infertility is also associated with genomic instability. High incidence of genomic instability in lymphocytes of women with polycystic 
ovary syndrome was revealed in the studies of Yesilada et al. (13) and Moran et al. (14). Moreover, couples with a history of spontaneous abortions and idiopathic infertility tend to have an increased micronuclei frequency in lymphocytes (15).

Micronuclei (MN) are defined as small, round nuclei clearly separated from the main cell nucleus which forms from acentric chromosome fragments or whole chromosome(s) during cell division. The frequency of $\mathrm{MN}$ as an index of chromosomal damage and genome instability is widely used for evaluating the genotoxic impact of demographic, habitual (16), occupational, and environmental factors $(17,18)$. Moreover, Bonassi et al. (19) consider that MN frequency may serve for predicting individual cancer risk.

Assuming that $\mathrm{MN}$ persistence in cells reflects chromosomal instability, the objective of this study was to evaluate spontaneous chromosomal damages in peripheral blood lymphocytes (PBL) of patients with reproductive failure and healthy controls by using cytokinesis-block micronucleus assay $(\mathrm{CBMN})$ in respect of the factors that may affect $\mathrm{MN}$ frequency (i.e. age, smoking habits, gender, miscarriages, and semen parameters).

\section{MATERIALS AND METHODS}

\section{Study populations}

This study has been approved by the Ethics Committee of the Clinic of Kragujevac (No 01-4886). It included 36 individual cases of reproductive failure (18 men and 18 women) refereed to the Clinical Centre of Kragujevac, Serbia. All participants were informed about the aim of the study and completed a standardised questionnaire that included standard demographic, medical, lifestyle, and occupational questions.

The mean age of male patients was $(35.22 \pm 6.68)$ years (range from 27 to 48 years). All of them underwent sperm analysis and three standard sperm parameters (sperm concentration, rapid progressive motility, and morphology) were determined. Numbers of spermatozoa per unit volume refers to the sperm concentration. Actively moving spermatozoa, linearly or in large circles, were scored for determining the progressive motility, while spermatozoa without malformations (head, neck, and tail defects) were scored for estimating the proportion of spermatozoa with normal morphology. Sperm concentration $\geq 20$ $\mathrm{x} 10^{6} \mathrm{~mL}^{-1}$, spermatozoa with rapid progressive motility $\geq 25 \%$, and normal sperm morphology $\geq 30 \%$ were referred to as normal values. The samples of five patients revealed azoospermia, four were diagnosed with abnormalities only in one parameter, two in two parameters, and three in all three major parameters. Four men from couples with idiopathic infertility were assigned to the infertile group despite normal sperm parameter values.

All male patients kept standard dietary habits. Nine of them were smokers.

Mean age of female patients was $(31.67 \pm 3.50)$ years (range from 24 to 37 years). Eleven of them were smokers and only one patient kept diet. Seven women had a history of miscarriages (ranged from 1 to 2 ).

The control sample included 15 age-matched healthy fertile male donors aging from 27 to 50 years [mean age (38.27 \pm 7.76$)$ years], and 15 agematched healthy fertile female donors, aging from 24 to 36 years [mean age $(32.4 \pm 2.99)$ years] without any recent exposure to known mutagenic agents. Fifteen of them ( 7 men and 8 women) were smokers.

\section{Cytokinesis - block micronucleus test (CBMN)}

We applied the CBMN test, as proposed by Fenech (20), for the analysis of MN frequency in peripheral blood lymphocytes. Heparinised whole blood was cultivated in the complete medium (PBMax Karyotyping, Invitrogen, USA) for a total of $72 \mathrm{~h}$ at $37^{\circ} \mathrm{C}$. Cytochalasin B (Sigma-Aldrich, USA), at a final concentration of $4 \mu \mathrm{g} \mathrm{mL}^{-1}$, was added to cultures after $44 \mathrm{~h}$ of incubation. Using the standard procedure, cells were harvested to prepare microscopic slides that were then stained in the $2 \%$ Giemsa solution (Alfapanon, Novi Sad, Serbia). The MN frequencies were determined by analysing 1000 $\mathrm{BN}$ cells per person following the standard criteria for scoring $\mathrm{MN}$ in BN cells as described by Fenech (21).

\section{Statistics}

Data were presented as mean \pm standard deviation (S.D.). The differences between baseline MN frequencies in lymphocytes in male patients and healthy men, healthy women and healthy men, among male samples, and among healthy female samples 
were compared using the Student's t-test. The differences between $\mathrm{MN}$ frequencies of female patients and female controls, male and female patients, and among female patients were determined using Mann-Whitney U test. The relationship between age, smoking status, and gender and MN frequency in both patients and control samples was determined by multiple linear regression analysis. The relationship between poor semen parameters and $\mathrm{MN}$ frequency was determined by Pearson's correlation. Level of significance was $\mathrm{p}<0.05$.

\section{RESULTS}

Results of the CBMN assay in PBL of patients with reproductive failure and PBL of healthy controls are shown in Tables 1-5.

We found significantly higher baseline $\mathrm{MN}$ frequencies $(\mathrm{p}<0.001)$ in female patients $[(13.50 \pm 2.50)$ $\mathrm{MN}$ per $1000 \mathrm{BN}$ cells] in comparison with healthy female controls [(6.80 2.98$) \mathrm{MN}$ per $1000 \mathrm{BN}$ cells] The mean $\mathrm{MN}$ frequency in male patients was significantly higher $(p=0.031)$ than in control healthy men $[(9.22 \pm 4.70) \mathrm{MN}$ per $1000 \mathrm{BN}$ cells vs. (6.27 \pm 2.66$) \mathrm{MN}$ per $1000 \mathrm{BN}$ cells]. In all samples gender affected $\mathrm{MN}$ rates, but only in patients was the sample statistically significant $(\mathrm{p}=0.011)$.

In all analysed samples, $\mathrm{BN}$ cells with $1 \mathrm{MN}$ were most frequently present. Cells with $2 \mathrm{MN}$ were less common, while BN cells with $3 \mathrm{MN}$ were found only in the patient sample (Table 3).

The mean MN frequency did not differ between smokers and non-smokers both in male patients and healthy men. Age had also no effect on the MN frequency in both analysed samples of men - patients and healthy controls.

Male patients were grouped according to their values for each analysed parameter. Statistical analyses for each analysed parameter (sperm concentration, rapid progressive motility, morphology) did not show any significant difference between the groups of

Table 1 General characteristics, micronuclei frequency and $M N$ distribution in male patients with reproductive failure

\begin{tabular}{|c|c|c|c|c|c|c|c|c|c|c|}
\hline \multirow[t]{2}{*}{ No } & \multirow{2}{*}{$\begin{array}{l}\text { Age / } \\
\text { year }\end{array}$} & \multirow{2}{*}{$\begin{array}{c}\text { Smoking } \\
\text { status } \\
(+/-)\end{array}$} & \multirow[t]{2}{*}{ Occupation } & \multicolumn{3}{|c|}{ Semen parameters } & \multirow{2}{*}{$\begin{array}{c}\text { MN } \\
\text { per1000 BN } \\
\text { cells }\end{array}$} & \multicolumn{3}{|c|}{ Distribution of MN } \\
\hline & & & & $\begin{array}{c}\text { Sperm } \\
\text { concentration / } \\
\times 10^{6} \mathrm{~mL}^{-1}\end{array}$ & $\begin{array}{c}\text { Rapid } \\
\text { progressive } \\
\text { motility / \% }\end{array}$ & $\begin{array}{c}\text { Normal } \\
\text { morphology } \\
/ \%\end{array}$ & & $1 \mathrm{MN}$ & $2 \mathrm{MN}$ & $3 \mathrm{MN}$ \\
\hline 1. & 32 & - & worker & 5.50 & 37 & 22 & 3 & 3 & 0 & 0 \\
\hline 2. & 44 & + & lawyer & 0 & 0 & 0 & 13 & 11 & 1 & 0 \\
\hline 3. & 30 & + & policeman & 0 & 0 & 0 & 9 & 9 & 0 & 0 \\
\hline 4. & 35 & - & engineer & 51.37 & 38 & 26 & 9 & 7 & 1 & 0 \\
\hline 5. & 48 & + & car mechanic & 1.10 & 9 & 19 & 6 & 6 & 0 & 0 \\
\hline 6. & 48 & - & instructor & 58.9 & 34 & 35 & 17 & 14 & 0 & 1 \\
\hline 7. & 41 & - & seller & 0 & 0 & 0 & 4 & 2 & 1 & 0 \\
\hline 8. & 29 & + & farmer & 89.50 & 39 & 45 & 9 & 9 & 0 & 0 \\
\hline 9. & 29 & + & doctor & 5.90 & 7 & 28 & 6 & 6 & 0 & 0 \\
\hline 10. & 28 & - & seller & 0 & 0 & 0 & 16 & 13 & 0 & 1 \\
\hline 11. & 40 & + & worker & 27.6 & 30 & 48 & 12 & 10 & 1 & 0 \\
\hline 12. & 31 & + & $\begin{array}{c}\text { driver/ } \\
\text { technician }\end{array}$ & 8.58 & 28 & 32 & 1 & 1 & 0 & 0 \\
\hline 13. & 38 & - & economist & 50.25 & 21 & 45 & 7 & 7 & 0 & 0 \\
\hline 14. & 36 & + & locksmith & 6.10 & 35 & 22 & 14 & 12 & 1 & 0 \\
\hline 15. & 36 & - & doctor & 0 & 0 & 0 & 14 & 8 & 3 & 0 \\
\hline 16. & 32 & - & engineer & 141.25 & 25 & 41 & 9 & 9 & 0 & 0 \\
\hline 17 & 27 & + & driver & 43.00 & 5 & 53 & 13 & 9 & 2 & 0 \\
\hline 18. & 30 & - & seller & 13.875 & 18 & 24 & 4 & 4 & 0 & 0 \\
\hline $\begin{array}{l}\text { Mean } \\
\pm \text { S.D. }\end{array}$ & $\begin{array}{r}35.22 \\
\pm 6.68 \\
\end{array}$ & & & $27.94 \pm 38.75$ & $18.11 \pm 15.41$ & $24.44 \pm 18.31$ & $9.22 \pm 4.70$ & $\begin{array}{c}7.78 \pm \\
3.67 \\
\end{array}$ & $\begin{array}{c}0.56 \pm \\
0.86 \\
\end{array}$ & $\begin{array}{c}0.11 \pm \\
0.32 \\
\end{array}$ \\
\hline
\end{tabular}


Table 2 General characteristics, micronuclei frequency and $M N$ distribution in female patients with reproductive failure

\begin{tabular}{|c|c|c|c|c|c|c|c|c|c|}
\hline \multirow[t]{2}{*}{ No } & \multirow{2}{*}{$\begin{array}{l}\text { Age / } \\
\text { year }\end{array}$} & \multirow{2}{*}{$\begin{array}{c}\text { Smoking } \\
\text { status } \\
(+/-)\end{array}$} & \multirow{2}{*}{$\begin{array}{c}\text { Dietary } \\
\text { status } \\
(+/-)\end{array}$} & \multirow[t]{2}{*}{ Occupation } & \multirow[t]{2}{*}{ Miscarriages } & \multirow{2}{*}{$\begin{array}{c}\text { MN per } 1000 \\
\text { BN cells }\end{array}$} & \multicolumn{3}{|c|}{ Distribution of MN } \\
\hline & & & & & & & $1 \mathrm{MN}$ & $2 \mathrm{MN}$ & $3 \mathrm{MN}$ \\
\hline 1. & 31 & - & - & engineer & 0 & 21 & 19 & 1 & 0 \\
\hline 2. & 35 & + & - & technician & 0 & 17 & 12 & 1 & 1 \\
\hline 3. & 36 & + & - & technician & 1 & 12 & 12 & 0 & 0 \\
\hline 4. & 32 & + & - & cook & 0 & 13 & 13 & 0 & 0 \\
\hline 5. & 34 & - & - & nurse & 0 & 15 & 13 & 1 & 0 \\
\hline 6. & 33 & - & - & doctor & 2 & 16 & 16 & 0 & 0 \\
\hline 7. & 31 & + & - & technician & 2 & 12 & 12 & 0 & 0 \\
\hline 8. & 37 & - & - & nurse & 0 & 14 & 12 & 1 & 0 \\
\hline 9. & 29 & + & - & locksmith & 0 & 11 & 9 & 1 & 0 \\
\hline 10. & 25 & + & - & worker & 0 & 12 & 10 & 1 & 0 \\
\hline 11. & 30 & + & - & worker & 0 & 13 & 13 & 0 & 0 \\
\hline 12. & 28 & - & - & seller & 2 & 14 & 12 & 1 & 0 \\
\hline 13. & 33 & + & - & cleaner & 0 & 13 & 11 & 1 & 0 \\
\hline 14. & 33 & - & + & seller & 1 & 12 & 12 & 0 & 0 \\
\hline 15. & 32 & + & - & technician & 1 & 11 & 11 & 0 & 0 \\
\hline 16. & 24 & + & - & worker & 0 & 13 & 11 & 1 & 0 \\
\hline 17. & 35 & + & - & housewife & 1 & 13 & 13 & 0 & 0 \\
\hline 18. & 32 & - & - & seller & 0 & 11 & 11 & 0 & 0 \\
\hline $\begin{array}{l}\text { Mean } \\
\pm \text { S.D. }\end{array}$ & $\begin{array}{c}31.67 \pm \\
3.50\end{array}$ & & & & & $13.50 \pm 2.50$ & $\begin{array}{c}12.33 \pm \\
2.22\end{array}$ & $\begin{array}{l}0.5 \pm \\
0.51\end{array}$ & $\begin{array}{c}0.05 \pm \\
0.23\end{array}$ \\
\hline
\end{tabular}

$M N$ - micronuclei, $B N$ - binucleated

Table 3 Micronuclei frequency and MN distribution in analysed patients and healthy controls

\begin{tabular}{|c|c|c|c|c|c|c|c|c|}
\hline & \multirow[t]{2}{*}{ No. } & \multirow{2}{*}{$\begin{array}{c}\text { Age / years } \\
\text { Mean } \pm \text { S.D. } \\
\text { (range) }\end{array}$} & \multirow{2}{*}{$\begin{array}{c}\text { No. of } \\
\text { analysed } \\
\text { cells }\end{array}$} & \multirow{2}{*}{$\begin{array}{c}\text { MN per } 1000 \text { BN cells } \\
\text { Mean } \pm \text { S.D. (range) }\end{array}$} & \multirow{2}{*}{$\begin{array}{c}\text { No. of } \\
\text { BN cell with } \\
\text { MN / \% }\end{array}$} & \multicolumn{3}{|c|}{ Distribution of MN (\%) } \\
\hline & & & & & & $\begin{array}{c}1 \mathrm{MN} \\
\text { No. }(\%)\end{array}$ & $\begin{array}{c}2 \mathrm{MN} \\
\text { No. }(\%)\end{array}$ & $\begin{array}{r}3 \mathrm{MN} \\
\text { No. }(\%)\end{array}$ \\
\hline Controls & 30 & & & & & & & \\
\hline Male & 15 & $\begin{array}{c}38.27 \pm 7.76 \\
(27 \text { to } 50)\end{array}$ & 15000 & $6.27 \pm 2.66$ ( 2 to 10$)$ & $92(0.61)$ & $90(0.60)$ & $2(0.01)$ & $0(0.0)$ \\
\hline Female & 15 & $\begin{array}{l}32.4 \pm 2.99 \\
(24 \text { to } 36)\end{array}$ & 15000 & $6.80 \pm 2.98(1 \text { to } 11)^{\mathrm{a}}$ & $102(0.68)$ & $102(0.68)$ & $0(0.0)$ & $0(0.0)$ \\
\hline Patients & 36 & & & & & & & \\
\hline Male & 18 & $\begin{array}{c}35.22 \pm 6.68 \\
(27 \text { to } 48)\end{array}$ & 18000 & $9.22 \pm 4.70(1 \text { to } 17)^{b}$ & $152(0.84)$ & $140(0.78)$ & $10(0.05)$ & $2(0.01)$ \\
\hline Female & 18 & $\begin{array}{c}31.67 \pm 3.50 \\
(24 \text { to } 37)\end{array}$ & 18000 & $13.50 \pm 2.5(11 \text { to } 21)^{\mathrm{c}, \mathrm{d}}$ & $232(1.29)$ & $222(1.23)$ & $9(0.05)$ & $1(0.01)$ \\
\hline
\end{tabular}

${ }^{a}$ no statistically significant difference in MN frequencies between healthy women and healthy men, $p=0.609$ (Student's t- test)

${ }^{b}$ statistically significant difference in $M N$ frequencies between male patients and male controls, $p=0.031$ (Student's t- test)

${ }^{c}$ statistically significant difference in MN frequencies between female patients and female controls, $p<0.001$ (Mann-Whitney $U$ test)

${ }^{d}$ statistically significant difference in MN frequencies between female patients and male patients, $p=0.011$ (Mann-Whitney $U$ test)

$M N$ - micronuclei, $B N$ - binucleated 
Table 4 Micronuclei frequencies in male patients and healthy male controls with regard to demographic, lifestyle and medical characteristics

\begin{tabular}{|c|c|c|}
\hline Groups (number) & $\begin{array}{c}\text { MN per } 1000 \text { BN cells } \\
\text { Mean } \pm \text { SD (range) }\end{array}$ & p value \\
\hline \multicolumn{3}{|l|}{ Patients ${ }^{\text {a }}$} \\
\hline \multicolumn{3}{|l|}{ Smoking status } \\
\hline Smoker (9) & $9.22 \pm 4.29(1$ to 14$)$ & \multirow{2}{*}{1.00} \\
\hline Non-smoker (9) & $9.22 \pm 5.33(3$ to 17$)$ & \\
\hline \multicolumn{3}{|l|}{ Age / years } \\
\hline 27 to $35(10)$ & $7.90 \pm 4.56(1$ to 16$)$ & \multirow{2}{*}{0.190} \\
\hline 36 to $48(8)$ & $10.87 \pm 4.61(4$ to 17$)$ & \\
\hline \multicolumn{3}{|l|}{ Semen parameters } \\
\hline \multicolumn{3}{|c|}{ Sperm concentration $/ \mathrm{x} 10^{6} \mathrm{~mL}^{-1}$} \\
\hline$<20(11)$ & $8.18 \pm 5.25(1$ to 16$)$ & \multirow{2}{*}{0.250} \\
\hline$\geq 20(7)$ & $10.86 \pm 3.39(7$ to 17$)$ & \\
\hline \multicolumn{3}{|c|}{ Rapid progressive motile spermatozoa (grade a) } \\
\hline$<25 \%(10)$ & $9.20 \pm 4.44(4-16)$ & \multirow{2}{*}{0.983} \\
\hline$\geq 25 \%(8)$ & $9.25 \pm 5.31(1-17)$ & \\
\hline \multicolumn{3}{|l|}{ Normal morphology } \\
\hline$<30 \%(11)$ & $8.91 \pm 4.68(3$ to 16$)$ & \multirow{2}{*}{0.734} \\
\hline$\geq 30 \%(7)$ & $9.71 \pm 5.06(1$ to 17$)$ & \\
\hline \multicolumn{3}{|l|}{ Healthy controls ${ }^{\text {a }}$} \\
\hline \multicolumn{3}{|l|}{ Smoking status } \\
\hline Smoker (7) & $6.00 \pm 2.31(3$ to 9$)$ & \multirow{2}{*}{0.731} \\
\hline Non-smoker (8) & $6.50 \pm 3.07(2$ to 10$)$ & \\
\hline \multicolumn{3}{|l|}{ Age / years } \\
\hline 27 to $39(9)$ & $6.55 \pm 3.13(2$ to 10$)$ & \multirow{2}{*}{0.624} \\
\hline 40 to $50(6)$ & $5.83 \pm 1.94(3$ to 8$)$ & \\
\hline
\end{tabular}

${ }^{a} M N$ frequencies between groups were compared by Student's t-test

$M N$ - micronuclei, $B N$ - binucleated

patients with normal values of semen parameters and those who had lower values (Table 4).

The mean MN frequency did not differ between non-smokers and smokers in both female patients and female healthy controls. In both analysed samples of women, patients and controls, age had no effect on the $\mathrm{MN}$ values. The MN frequency between female patients with and without miscarriage history was not significantly different (Table 5).

Multiple linear regression analyses showed that among the analysed confounding factors (i.e., age, smoking habits, and gender), only gender had a significant effect on the MN values in the analysed sample of patients $(p=0.001)$. Neither of the analysed factors affected $\mathrm{MN}$ frequency in the analysed healthy control sample.

The result of Pearson's correlation analyses showed a negative correlation between poor values of sperm concentration $\left(<20 \times 10^{6} \mathrm{~mL}^{-1}\right)$, rapid progressive motility $(<25 \%)$, normal morphology $(<30 \%)$ and
MN frequencies but without statistical significance $(\mathrm{r}=-0.524, \mathrm{p}=0.098 ; \mathrm{r}=-0.545, \mathrm{p}=0.103 ; \mathrm{r}=-0.463$, $\mathrm{p}=0.152$ ).

\section{DISCUSSION}

Chromosomal instability can be defined as an increased rate of numerical and structural chromosomal changes during cell division. Different human health problems are associated with chromosomal instability in lymphocytes (22-24). Today, cytogenetics provides numerous different biomarkers for evaluating chromosomal instability and scoring of $\mathrm{MN}$ in lymphocytes is one that draws a lot of interest.

Our results show that mean $\mathrm{MN}$ frequencies in both male and female patients increased in comparison with mean $\mathrm{MN}$ frequencies of healthy male and female controls. The approximately 1.5 - 
Table 5 Micronuclei frequencies in female patients and healthy female controls with regard to demographic, lifestyle and medical characteristics

\begin{tabular}{|c|c|c|}
\hline Groups (number) & $\begin{array}{l}\text { MN per } 1000 \text { BN cells } \\
\text { Mean } \pm \text { SD (range) }\end{array}$ & p value \\
\hline \multicolumn{3}{|l|}{ Patients $^{\text {a }}$} \\
\hline \multicolumn{3}{|l|}{ Smoking status } \\
\hline Smoker (11) & $12.73 \pm 1.62$ (11 to 17$)$ & \multirow{2}{*}{0.117} \\
\hline Non-smoker (7) & $14.71 \pm 3.25(11$ to 21$)$ & \\
\hline \multicolumn{3}{|l|}{ Age / years } \\
\hline 24 to $31(7)$ & $13.71 \pm 3.35$ (11 to 21$)$ & \multirow{2}{*}{0.854} \\
\hline 32 to 37 (11) & $13.36 \pm 1.96$ (11 to 17$)$ & \\
\hline \multicolumn{3}{|c|}{ History of miscarriages } \\
\hline Yes (7) & $12.86 \pm 1.68$ (11 to 16$)$ & \multirow{2}{*}{0.433} \\
\hline No (11) & $13.91 \pm 2.91$ (11 to 21$)$ & \\
\hline \multicolumn{3}{|l|}{ Healthy controls ${ }^{b}$} \\
\hline \multicolumn{3}{|l|}{ Smoking status } \\
\hline Smoker (8) & $6.25 \pm 3.24$ (1 to 11$)$ & \multirow{2}{*}{0.465} \\
\hline Non-smoker (7) & $7.43 \pm 2.76$ (4 to 11$)$ & \\
\hline \multicolumn{3}{|l|}{ Age / years } \\
\hline 24 to $32(6)$ & $6.83 \pm 2.99$ (3 to 11$)$ & \multirow{2}{*}{0.973} \\
\hline 33 to $36(9)$ & $6.78 \pm 3.15$ ( 1 to 11$)$ & \\
\hline
\end{tabular}

$M N$ - micronuclei, $B N$ - binucleated

${ }^{a} M N$ frequencies between groups were compared by Mann-Whitney U test

${ }^{b} M N$ frequencies between groups were compared by Student's t- test

fold $\mathrm{MN}$ increase in male patients and more than a two-fold MN increase in female patients indicated greater chromosomal damages in PBL of patients with reproductive failure. Recently, the association between MN frequency in PBL and impaired reproductive history has been reviewed by Fenech (25).

Similar, De Palma et al. (26) demonstrated an increase in sex chromosome aneuploidy rate in peripheral leukocytes of patients with impaired spermatogenesis and suggested that they had generalised defective cell division mechanism. Higher MN frequency in analysed patients with reproductive failure may be explained by abnormality in the mechanism that controls division.

Increased $\mathrm{MN}$ frequencies in patients may also be the consequences of oxidative stress (OS), which has been considered a contributing factor to infertility. The events that lead to MN formation in the cells may be induced by OS (19).

In our study, we obtained a great inter-individual variation in $\mathrm{MN}$ frequencies. Age, smoking, gender, dietary habits, and individual susceptibility to environmental or occupational mutagens are factors that account for the $\mathrm{MN}$ frequency variation.
According to Fenech (27), age is an important demographic contributing factor. The same age effect on MN was reported in the studies of Ishikawa et al. (16) and Mahrous (28). In our study, age had no effect on $\mathrm{MN}$ frequency in both healthy subjects' and patients' samples. Trkova et al. (15) explained the lack of significant correlation between age and MN frequency by age homogeneity of tested samples. Besides this explanation, the lack of effect of age on MN frequency in analysed samples might be due to a small range of years. However, these results have to be confirmed in larger samples primarily designed to evaluate the effect of age.

Gender, as one of the contributing factors, was analysed in many studies. In most of them, MN frequencies have been reported to be higher in women than in men $(27,29)$; generally by 1.2 to 1.6 times (27). This appearance could be explained by over-prevalence of $\mathrm{X}$ chromosome in female $\mathrm{MN}$ (30). Although in our study, women had higher $\mathrm{MN}$ frequency in both healthy control and patient samples, a significant difference in $\mathrm{MN}$ frequencies was evident only in the patient sample. Women had approximately 1.5 -fold higher MN frequency than analysed male patients. 
In addition to age and gender, smoking habits may modulate $\mathrm{MN}$ frequency. Bonassi et al. (31) reported a significant effect of smoking on $\mathrm{MN}$ frequency only in the heavy-smoker group. In the present study, we did not find a statistically significant difference in $\mathrm{MN}$ frequency between smokers and non-smokers. No association between smoking habit and $\mathrm{MN}$ frequency was also observed in the study of Hessel et al. (32) and Costa et al. (33). It is possible that exposure to genotoxic substances from cigarette smoke induces serious impairments of cell division or cell death. However, negative results of CBMN assay in smokers might be explained by the "escape" of highly damaged cells from scoring. Contrary to these, micronucleated cells with one $\mathrm{MN}$ and less genome damages have a better chance of surviving (34). Thus, Bonassi et al. (31) explain that if damaged cells do not divide, they will not form binucleated cells, so these will not be scored for MN. Furthermore, adaptive response is often mentioned as a possible reason for lower $\mathrm{MN}$ frequency in the PBL of light - medium smokers $(31,35)$.

With regard to miscarriage history, in the analysed patient sample, women with a history of miscarriages had the same level of chromosomal damages in PBL as women with no conception in reproductive history. According to the study of Milošević-Djordjević et al. (36) and an earlier study of Grujičić et al. (37), women with threaded miscarriages had an increased $\mathrm{MN}$ frequency in lymphocytes and this could be the explanation for MN similarity between analysed women.

In our study, male patients with poor semen parameters did not have a significantly lower MN frequency in PBL compared to patients with normal values of semen parameters. As in smokers, lower $\mathrm{MN}$ frequencies in these patients might be explained by greater genome damages in their lymphocytes that escaped from scoring.

Although we did not find a statistically significant association between the levels of chromosomal instability (presented in the form of $\mathrm{MN}$ ) and poor semen quality, negative correlation between these two parameters points to a tendency of higher chromosomal damages in PBL of infertile men.

\section{CONCLUSION}

From the present study it is evident that an increase in the baseline MN frequency in PBL of untreated men and women with reproductive failure corresponds to the increase in chromosomal damage, which occurs as a result of complex events that cause reproductive disorders.

\section{Acknowledgments}

The study was supported by the Ministry of Education, Science and Technological Development of the Republic of Serbia (Grant No III 41010 and 175103).

\section{REFERENCES}

1. Layman LC. Human gene mutations causing infertility. J Med Genet 2002;39:153-61.

2. Poongothai J, Gopenath TS, Manonayaki S. Genetics of human male infertility. Singapore Med J 2009;50:336-47.

3. Malik A, Jain S, Hakim S, Shukla I, Rizvi M. Chlamydia trachomatis infection \& female infertility. Indian J Med Res 2006;123:770-5.

4. Homan GF, Davies M, Norman R. The impact of lifestyle factors on reproductive performance in the general population and those undergoing infertility treatment: a review. Hum Reprod Update 2007;13:209-23.

5. Dhont N, van de Wijgert J, Luchters S, Muvunyi C, Vyankandondera J, Temmerman M. Sexual violence, HSV2 and HIV are important predictors for infertility in Rwanda. Hum Reprod 2010;25:2507-15.

6. Hristova R, Ko E, Greene C, Rademaker A, Chernos J, Martin R. Chromosome abnormalities in sperm from infertile men with asthenoteratozoospermia. Biol Reprod 2002;66:1781-3.

7. Schmid TE, Brinkworth MH, Hill F, Sloter E, Kamischke A, Marchetti F, Nieschlag E, Wyrobek AJ. Detection of structural and numerical chromosomal abnormalities by ACM-FISH analysis in sperm of oligozoospermic infertility patients. Hum Reprod 2004;19:1395-400.

8. Nagvenkar P, Desai K, Hinduja I, Zaveri K. Chromosomal studies in infertile men with oligozoospermia \& non obstructive azoospermia. Indian J Med Res 2005;122:3442.

9. Ceylan GG, Ceylan C, Elyas H. Genetic anomalies in patients with severe oligozoospermia and azoospermia in eastern Turkey: a prospective study. Genet Mol Res 2009;8:91522.

10. Schmid TE, Kamischke A, Bollwein H, Nieschlag E, Brinkworth MH. Genetic damage in oligozoospermic patients detected by fluorescence in-situ hybridization, inverse restriction site mutation assay, sperm chromatin structure assay and the Comet assay. Hum Reprod 2003;18:1474-80.

11. Shamsi MB, Venkatesh S, Tanwar M, Singh G, Mukherjee S, Malhotra N, Kumar R, Gupta NP, Mittal S, Dada R. Comet assay: a prognostic tool for DNA integrity assessment in infertile men opting for assisted reproduction. Indian J Med Res 2010;131:675-81. 
12. Duzcan F, Aybek Z, Tepeli E, Caner V, Cetin GO, Aybek H, Bagci H. Sex chromosome aneuploidy rates in the somatic cells of infertile men. J Reprod Med 2006;51:489-92.

13. Yesilada E, Sahin I, Ozcan H, Yildirim IH, Yologlu S, Taskapan C. Increased micronucleus frequencies in peripheral blood lymphocytes in women with polycystic ovary syndrome. Eur J Endocrinol 2006;154:563-8.

14. Moran LJ, Noakes M, Clifton PM, Norman RJ, Fenech MF. Genome instability is increased in lymphocytes of women with polycystic ovary syndrome and is correlated with insulin resistance. Mutat Res 2008;639:55-63.

15. Trková M, Kapras J, Bobková K, Stanková J, Mejsnarová $B$. Increased micronuclei frequencies in couples with reproductive failure. Reprod Toxicol 2000;14:331-5.

16. Ishikawa $H$, Tian $Y$, Yamauchi $T$. Influence of gender, age and lifestyle factors on micronuclei frequency in healthy Japanese populations. J Occup Health 2003;45:179-81.

17. Minozzo R, Deimling LI, Gigante LP, Santos-Mello R. Micronuclei in peripheral blood lymphocytes of workers exposed to lead. Mutat Res 2004;565:53-60.

18. Pedersen M, Vinzents P, Petersen JH, Kleinjans JC, Plas G, Kirsch-Volders M, Dostál M, Rossner P, Beskid O, Sram RJ, Merlo DF, Knudsen LE. Cytogenetic effects in children and mothers exposed to air pollution assessed by the frequency of micronuclei and fluorescence in situ hybridization (FISH): A family study in the Czech Republic. Mutat Res 2006;608:112-20.

19. Bonassi S, Znaor A, Ceppi M, Lando C, Chang WP, Holland N, Kirsch-Volders M, Zeiger E, Ban S, Barale R, Bigatti MP, Bolognesi C, Cebulska-Wasilewska A, Fabianova E, Fucic A, Hagmar L, Joksic G, Martelli A, Migliore L, Mirkova E, Scarfi MR, Zijno A, Norppa H, Fenech M. An increased micronucleus frequency in peripheral blood lymphocytes predicts the risk of cancer in humans. Carcinogenesis 2007;28:625-31

20. Fenech $\mathrm{M}$. The cytokinesis-block micronucleus technique: a detailed description of the method and its application to genotoxicity studies in human populations. Mutat Res 1993;285:35-44.

21. Fenech M. Cytokinesis-block micronucleus cytome assay. Nat Protoc 2007;2:1084-104.

22. Botto N, Rizza A, Colombo MG, Mazzone AM, Manfredi S, Masetti S, Clerico A, Biagini A, Andreassi MG. Evidence for DNA damage in patients with coronary artery disease. Mutat Res 2001;493:23-30.

23. Petrozzi L, Lucetti C, Scarpato R, Gambaccini G, Trippi F, Bernardini S, Del Dotto P, Migliore L, Bonuccelli U. Cytogenetic alterations in lymphocytes of Alzheimer's disease and Parkinson's disease patients. Neurol Sci 2002;23(Suppl 2):S97-8.

24. Milošević-Djordjević $\mathrm{O}$, Grujičić $\mathrm{D}$, Vasković Z, Marinković D. High micronucleus frequency in peripheral blood lymphocytes of untreated cancer patients irrespective of gender, smoking and cancer sites. Tohoku J Exp Med 2010;220:115-20.
25. Fenech M. Micronuclei and their association with sperm abnormalities, infertility, pregnancy loss, pre-eclampsia and intra-uterine growth restriction in humans. Mutagenesis 2011;26:63-7.

26. De Palma A, Burrello N, Barone N, D'Agata R, Vicari E, Calogero AE. Patients with abnormal sperm parameters have an increased sex chromosome aneuploidy rate in peripheral leukocytes. Hum Reprod 2005;20:2153-6.

27. Fenech M. Important variables that influence base-line micronucleus frequency in cytokinesis-blocked lymphocytesa biomarker for DNA damage in human populations. Mutat Res 1998;404:155-65.

28. Mahrous HS. Effects of age, gender, folate and vitamin $B_{12}$ status on DNA damage. Bull Alex Fac Med 2009;45:195200.

29. Bolognesi C, Perrone E, Landini E. Micronucleus monitoring of a floriculturist population from western Liguria, Italia. Mutagenesis 2002;17:391-7.

30. Catalán J, Autio K, Kuosma E, Norppa H. Age-dependent inclusion of sex chromosomes in lymphocyte micronuclei of man. Am J Hum Genet 1998;63:1464-72.

31. Bonassi S, Neri M, Lando C, Ceppi M, Lin YP, Chang WP, Holland N, Kirsch-Volders M, Zeiger E, Fenech M; HUMN collaborative group. Effect of smoking habit on the frequency of micronuclei in human lymphocytes: results from the Human MicroNucleus project. Mutat Res 2003;543:15566.

32. Hessel H, Radon K, Pethran A, Maisch B, Grobmair S, Sautter I, Fruhmann G. The genotoxic risk of hospital, pharmacy and medical personnel occupationally exposed to cytostatic drugs - evaluation by the micronucleus assay. Mutat Res 2001;497:101-9.

33. Costa C, Teixeira JP, Silva S, Roma-Torres J, Coelho P, Gaspar J, Alves M, Laffon B, Rueff J, Mayan O. Cytogenetic and molecular biomonitoring of a Portuguese population exposed to pesticides. Mutagenesis 2006;21:343-50.

34. Hando JC, Tucker JD, Davenport M, Tepperberg J, Nath $\mathrm{J}$. X chromosome inactivation and micronuclei in normal and Turner individuals. Hum Genet 1997;100:624-8.

35. Garaj-Vrhovac V, Durinec M, Kopjar N, Oreščanin V. A survey on the cytogenetic status of the Croatian general population by use of the cytokinesis-block micronucleus assay. Mutat Res 2008;649:91-100.

36. Milošević-Djordjević O, Grujičić D, Marinković D, Arsenijević S, Banković S. Effect of various doses of gestogens on micronuclei frequency in human peripheral blood lymphocytes of pregnant women. Hum Reprod 2003;18:433-6.

37. Grujičić D, Milošević-Djordjević O, Marinković D, Arsenijević S, Banković S, Živanović A, Dimitrijević A. Effect of gestagens on micronucleus frequency in human peripheral blood lymphocytes. Balk J Med Genet 1999;2:238. 


\section{Sažetak \\ PROCJENA KROMOSOMSKE NESTABILNOSTI U LIMFOCITIMA PERIFERNE KRVI BOLESNIKA S POREMEĆAJIMA REPRODUKTIVNOG SUSTAVA POMOĆU MIKRONUKLEUS-TESTA}

Ispitivali smo kromosomsku nestabilnost u limfocitima periferne krvi (engl. peripheral blood lymphocytes - PBL) bolesnika s poremećajima reproduktivnog sustava u odnosu na parametre dobi, navike pušenja, spola, spontanih pobačaja i kvalitete sjemena. Ispitivanje je uključivalo 36 pojedinačnih ispitanika $\mathrm{S}$ poremećajima reproduktivnog sustava (18 muškaraca i 18 žena) u Kliničkom centru u Kragujevcu, Srbiji, te 30 zdravih ispitanika (15 muškaraca i 15 žena). Učestalost pojave mikronukleusa (MN) utvrđena je u PBL-ima primjenom mikronukleus-testa s tehnikom blokirane citokineze (engl. cytokinesis-block micronucleus - CBMN). Učestalosti MN bile su značajno povišene $(p=0,031 ; p<0,001)$ kod muških

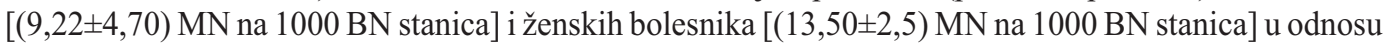
na osnovne vrijednosti utvrđene u muških i ženskih zdravih kontrolnih ispitanika $[(6,27 \pm 2,66) \mathrm{MN}$ na 1000 BN stanica; $(6,80 \pm 2,98)$ MN na 1000 BN stanica]. Prosječna se učestalost MN nije značajno razlikovala među skupinama kod kojih je došlo do spontanih pobačaja te među skupinama koje su imale normalne vrijednosti parametara kvalitete sjemena i onih koje nisu imale takve vrijednosti. Korelacije između niske koncentracije spermija $\left(<20 \times 10^{6} \mathrm{~mL}^{-1}\right)$, smanjene pokretljivosti spermija $(<25 \%)$, normalne morfologije $(<30 \%)$ i učestalosti MN bile su negativne, ali ne i statistički značajne. Utvrdili smo da je samo spol značajno utjecao na pojavnost MN u svih ispitanih bolesnika. Nije bilo značajnih razlika između dobnih skupina, kao ni između pušača i nepušača kod bolesnika i kontrolnih ispitanika. Zaključujemo da pojavnost MN u limfocitima bolesnika s poremećajima reproduktivnog sustava prati porast razine kromosomskih oštećenja koja nastaju kao posljedica složenih događaja koji uzrokuju poremećaje reproduktivnog sustava.

KLJUČNE RIJEČI: dob, kvaliteta sjemena, spol, mikronukleusi, neplodnost, pušenje

\section{CORRESPONDING AUTHOR:}

Olivera Milošević-Djordjević

Faculty of Science, University of Kragujevac

Radoja Domanovića 12, P.O. Box 60

34000 Kragujevac, Serbia

E-mail: olivera@kg.ac.rs 